\title{
COMBINED EFFECTS OF STRAW RETURNING AND NITROGEN FERTILIZER APPLICATION ON CROP YIELD AND NITROGEN UTILIZATION IN THE CHERNOZEM OF NORTHEAST CHINA
}

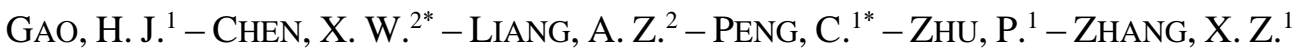 \\ ${ }^{1}$ Institute of Agricultural Resource and Environment, Jilin Academy of Agricultural Sciences, \\ Changchun 130033, China \\ ${ }^{2}$ Key Laboratory of Mollisols Agroecology, Northeast Institute of Geography and Agroecology, \\ Chinese Academy of Sciences, Changchun 130102, China \\ *Corresponding authors \\ e-mail: chenxuewen@iga.ac.cn (Chen, X.W.); pengchang2005@163.com (Peng, C.)
}

(Received $13^{\text {th }}$ Oct 2021; accepted $22^{\text {nd }}$ Dec 2021)

\begin{abstract}
Balancing the relationship between straw returning and fertilizer, especially nitrogen fertilizer application is vital for achieving the goal of reducing fertilization and improving soil fertility. To better understand their combined effects on crop yield and nitrogen utilization, a study was conducted to explore the effects of straw returning and nitrogen fertilizer application on crop yield and nitrogen utilization. In contrast to straw return, nitrogen fertilizer application had a more significant effect on the crop yield. Straw ploughing led to significantly higher crop yield under the nitrogen fertilizer application rates of 0,90 , $150 \mathrm{~kg} / \mathrm{ha}$ compared to straw mulching $(\mathrm{P}<0.05)$. No significant differences for $>150 \mathrm{~kg} / \mathrm{ha}$ concerning their effects on crop yield were observed between straw ploughing and mulching. The optimal residual return amount was $9000 \mathrm{~kg} / \mathrm{ha}$ and straw return was not decisive to crop yield under the same nitrogen fertilizer application rate. Straw ploughing better promoted nitrogen uptake, utilization, harvest and retention than straw mulching and no residue addition when combined with nitrogen fertilizer application. These findings demonstrate that straw ploughing and $150 \mathrm{~kg} / \mathrm{ha}$ nitrogen fertilizer application rate is a better combination for implementing stable production and enhancing nitrogen utilization synchronously in the chernozem of Northeast China.
\end{abstract}

Keywords: straw ploughing, straw mulching, residual return amount, corn nitrogen uptake, soil total nitrogen

\section{Introduction}

Soil nitrogen is an essential nutrient for plant growth and development in an ecosystem meanwhile an important element that restricts crop yield (Osterholz et al., 2018). Proper application of nitrogen fertilizer is an effective means to increase crop yield (Tenelli et al., 2021). However, in order to achieve high yields, people over apply nitrogen fertilizer that exceeds the requirements of plants ( $\mathrm{Li}$ et al., 2021). Excessive application of nitrogen fertilizer not only resulted in serious waste of nitrogen fertilizer, but also reduced utilization rate and significantly increased apparent loss (Ahmed et al., 2017). At the same time, it led to a series of environmental problems (water pollution, soil acidification, greenhouse effect, etc.) (Huang et al., 2018; Asibi et al., 2019; Rahman et al., 2021). Therefore, reduced fertilization is the development trend of future farmland management and crop production.

Nonetheless, significant reduction in the application of nitrogen fertilizer will affect crop growth (Ruffatti et al., 2019). Hence, on the basis of proper fertilization, reasonable utilization of the soil's own capacity to provide fertilizer and the adoption of a reasonable way to cultivate fertilizer are the main ways to improve the utilization rate of nitrogen 
fertilizer, reduce environmental pollution, and improve crop yield and quality (Dimkpa et al., 2020). Straw returning is an effective measure to cultivate fertilizer and it can increase soil organic matter content and nutrient recycling efficiency, balance crop nutrients, and significantly change the relationship between source and reservoir in crop (Wang et al., 2018). C/N ratio in crop straw is relatively high which often causes soil nitrogen fixation after straw returning to the field (Farooq et al., 2019). In such a condition, this will reduce soil nitrogen supply capacity and affect crop growth and thus it is necessary to apply nitrogen fertilizer to ensure the nitrogen supply after straw returning to the field (Weih et al., 2018). On the other hand, straw returning alone cannot meet the nutrient demand of crops and cannot achieve high yield whereas nitrogen fertilizer application could increase crop yield by increasing effective panicle number, grain number per panicle and grain weight (Guan et al., 2020). Therefore, combined application of straw returning and nitrogen fertilizer may increase crop yield more effectively, and it is also considered as an effective tillage management practice (Mabagala et al., 2020). However, the combined effects of straw returning and nitrogen fertilizer application on crop yield is as yet largely unknown.

On the other hand, the relationship between straw returning and nitrogen fertilizer utilization rate is still controversial. Some studies have pointed out that straw returning would reduce the nitrogen fertilizer utilization rate, there also exists opposite views (Dimkpa et al., 2020; Janke et al., 2020). Moreover, straw returning also affects nitrogen uptake and crop yield (Ma et al., 2021). The main reason for this is whether or not straw returning affect nitrogen utilization and crop yield alone. Thus we hypothesized that combined application of straw returning and nitrogen fertilizer application rates when there is a specific combination between them could stabilize crop yield and improve nitrogen utilization simultaneously. Furthermore, since chernozem is not as common as mollisol in Northeast China, and little information was available on the influence of straw returning and nitrogen fertilizer application on crop yield and nitrogen utilization in chernozem, more data in the comparison are required for the soil protection work in Northeast China.

Consequently, the objectives of this study were to (1) compare the effects of straw returning and nitrogen fertilizer application on crop yield and (2) analyze the effects of straw returning and nitrogen fertilizer application on nitrogen utilization. The present study may provide technical reference for the rational application of nitrogen fertilizer and the increment of corn yield under straw returning in dryland agricultural production conditions.

\section{Materials and methods}

\section{Field site and treatments}

The studied area was established in 2011 at the Experimental Station $\left(44^{\circ} 56^{\prime} \mathrm{N}\right.$, $125^{\circ} 18^{\prime} \mathrm{E}$ ) of Jilin Academy of Agricultural Sciences, in Nong' an County, Jilin Province, Northeast China. It has a mid-temperate continental monsoon climate with the mean annual temperature of $4.7^{\circ} \mathrm{C}$. The mean annual precipitation was $507.7 \mathrm{~mm}$. The soil type studied in the present study was typical chernozem with a high $\mathrm{pH}$ value $(\mathrm{pH}>7)$ and a high calcium carbonate $\left(\mathrm{CaCO}_{3}\right)$ content according to FAO (1998). Prior to the establishment of the current experiment, detailed soil chemical properties in $0-20 \mathrm{~cm}$ depth were as follows: $22.3 \mathrm{~g} / \mathrm{kg}$ of soil organic matter, $1.537 \mathrm{~g} / \mathrm{kg}$ of soil total nitrogen, $0.565 \mathrm{~g} / \mathrm{kg}$ of soil total phosphorus, $22.7 \mathrm{~g} / \mathrm{kg}$ of soil total potassium, $128.2 \mathrm{mg} / \mathrm{kg}$ of soil 
alkali-hydrolyzable nitrogen, $12.9 \mathrm{mg} / \mathrm{kg}$ of soil rapid available phosphorus, $132.5 \mathrm{mg} / \mathrm{kg}$ of soil rapid available potassium, 7.75 of soil $\mathrm{pH}$.

\section{Experimental design}

The current experiment included two parts: (1) The objective for the first part was to compare the effects of different straw returning methods and different nitrogen fertilizer application rates. Under the same residual return amount $(9000 \mathrm{~kg} / \mathrm{ha})$ to the field, six nitrogen fertilizer application rates level of 0 (N0), 90 (N6), 150 (N10), 210 (N14), 270 $(\mathrm{N} 18), 330(\mathrm{~N} 22) \mathrm{kg} / \mathrm{ha}$ combined with 2 straw returning methods (straw ploughing and straw mulching). $9000 \mathrm{~kg} / \mathrm{ha}$ was the residual return amount for local farmers (Zhao et al., 2019). Different residual return amount (0, 4500, 9000, $13500 \mathrm{~kg} / \mathrm{ha})$ and different straw returning methods (straw ploughing, straw mulching and no residue addition) under the same fertilizer application rate $(210 \mathrm{~kg} / \mathrm{ha})$ was also involved in this part; (2) The objective for the second part was to compare the effects of straw returning and nitrogen fertilizer application on nitrogen utilization. Three straw returning methods (straw ploughing, straw mulching and no residue addition) under the same fertilizer application rate $(210 \mathrm{~kg} / \mathrm{ha})$ was included in this part.

All the above treatments were arranged in a randomized complete block design with three replicates. Each treatment plot was $80 \mathrm{~m}^{2}$. Phosphorus and potash fertilizers were applied as starter fertilizer at rates of $105 \mathrm{~kg}$ P/ha and $105 \mathrm{~kg} \mathrm{~K} / \mathrm{ha}$. For straw ploughing, after corn harvest, the straw was artificially scattered in each treatment plot according to the different application amount of corn straw, and then the straw was crushed by a straw grinder (the length was less than $6 \mathrm{~cm}$ ), and the straw was returned to the field with a depth of about $16 \mathrm{~cm}$ by a high-horsepower agricultural machine to deep spiral, so that the straw was fully and evenly mixed with the soil, and finally the straw was heavily compressed. For straw mulching, after corn harvest, the straw crusher was used to crush the straw (the length was below $10 \mathrm{~cm}$ ), and the no-tillage planter was used to complete the sowing, fertilization and repression operation at one time. Single column vibration local deep loosening operation was used once a year, and the depth of deep loosening was about $30 \mathrm{~cm}$. Corn cultivar planted in the experimental plot was Pioneer Corn 335 planted at a density of 60, 000 plants/ha. One third of the nitrogen applied to corn was applied as starter fertilizer before spring sowing, the remaining $2 / 3$ nitrogen fertilizer was topdressing at jointing stage. Nutrient content in corn straw was $42.6 \% \mathrm{C}, 0.8 \% \mathrm{~N}, 0.32 \%$ $\mathrm{P}_{2} \mathrm{O}_{5}, 0.75 \% \mathrm{~K}_{2} \mathrm{O}$, respectively. Corn was sown on or about April 28 and harvested on or about September 27 each year, plant spacing and row spacing were $65 \mathrm{~cm}$ and $18 \mathrm{~cm}$, respectively, and field management measures were consistent in each treatment period.

\section{Sampling and analysis}

Three representative plants were taken in each plot at the mature stage of corn in 2016, which were divided into four parts: stem, leaf (bract), grain and shaft. The plants were de-enzyme at $105^{\circ} \mathrm{C}$ for $30 \mathrm{~min}$, dried at $80^{\circ} \mathrm{C}$ to constant weight, and weighed as dry matter weight. Then all the samples were smashed and sifted $0.05 \mathrm{~mm}$, and $\mathrm{H}_{2} \mathrm{SO}_{4}-\mathrm{H}_{2} \mathrm{O}_{2}$ digestion. The nitrogen content of plant samples was determined by Kjeldahl method. At the same time, composite soil samples were collected down to a depth of $20 \mathrm{~cm}$ from each plot using a manual soil probe and then used Elemental Analyzer to determine soil total nitrogen. 


\section{Nitrogen partial factor productivity and nitrogen harvest index determination}

Nitrogen partial factor productivity $(\mathrm{kg} / \mathrm{kg}$ ) was calculated by formula (1) (Sawyer et al., 2017):

$$
\text { Nitrogen partial factor productivity }=\frac{\text { Grain yield }}{\text { Fertilizer nitrogen input }}
$$

Nitrogen harvest index (\%) calculation was according to formula (2) (Chen et al., 2011):

$$
\text { Nitrogen harvest index }=\frac{\text { Nitrogen uptake by grains }}{\text { Nitrogen uptake by plants }} \times 100 \%
$$

\section{Statistical analysis}

The SPSS 13.0 software (SPSS Inc., Chicago, USA) was used for all of the statistical analyses. Multifactor interactions among the straw returning method, residual return amount and nitrogen fertilizer application rates on crop yield were used for an $F$-test analysis at a statistical significance of the 5\% level. Treatment main effects on crop yield under the combination of straw returning and nitrogen fertilizer application, and under the same fertilizer application rate were tested using one-way analysis of variance (ANOVA). Treatment main effects on corn nitrogen uptake, nitrogen partial factor productivity, nitrogen harvest index and soil total nitrogen applied the above same statistical analysis method. Treatment means were compared using the least significant difference (LSD) at $\mathrm{P}<0.05$. Analysis of variance was used to test for differences in resulting crop yield for straw returning method and nitrogen fertilizer application. A probability value of 0.05 was used to delineate significant treatment effects.

\section{Results}

\section{Effects of straw returning and nitrogen fertilizer application on crop yield}

A multifactor interaction analysis was conducted to better understanding the effect of straw returning method (SRM), residual return amount (RRA) and nitrogen fertilizer application rates (NFAR) on crop yield (Table 1). According to the significant p-value for analysis of variance $F$-test, SRM and RRA did not have significant effect on crop yield (Table 1). NFAR and SRM $\times$ NFAR significantly affected crop yield (Table 1).

Table 1. Significant p-value for analysis of variance F-test for crop yield as affected by straw returning method (SRM), residual return amount (RRA) and nitrogen fertilizer application rates $(N F A R)$

\begin{tabular}{c|c|c|c|c|c|c|c}
\hline & SRM & RRA & NFAR & SRM $\times$ RRA & SRM $\times$ NFAR & RRA $\times$ NFAR & SRM $\times$ RRA $\times$ NFAR \\
\hline Crop yield & 0.089 & 0.747 & $0.000^{* *}$ & 0.995 & $0.000^{* *}$ & 0.986 & 1 \\
\hline
\end{tabular}

**Significant at $1 \%$ level

Straw ploughing led to significantly increment of crop yield under N0, N10 compared to straw mulching by $37.47 \%$ and $6.21 \%$, respectively $(\mathrm{P}<0.05)$, N6 treatment was not significant (Fig. 1). However, no significant differences were observed for nitrogen 
fertilizer application rates $>150 \mathrm{~kg} / \mathrm{ha}(\mathrm{N} 14, \mathrm{~N} 18, \mathrm{~N} 22)$ between straw ploughing and straw mulching (Fig. 1).

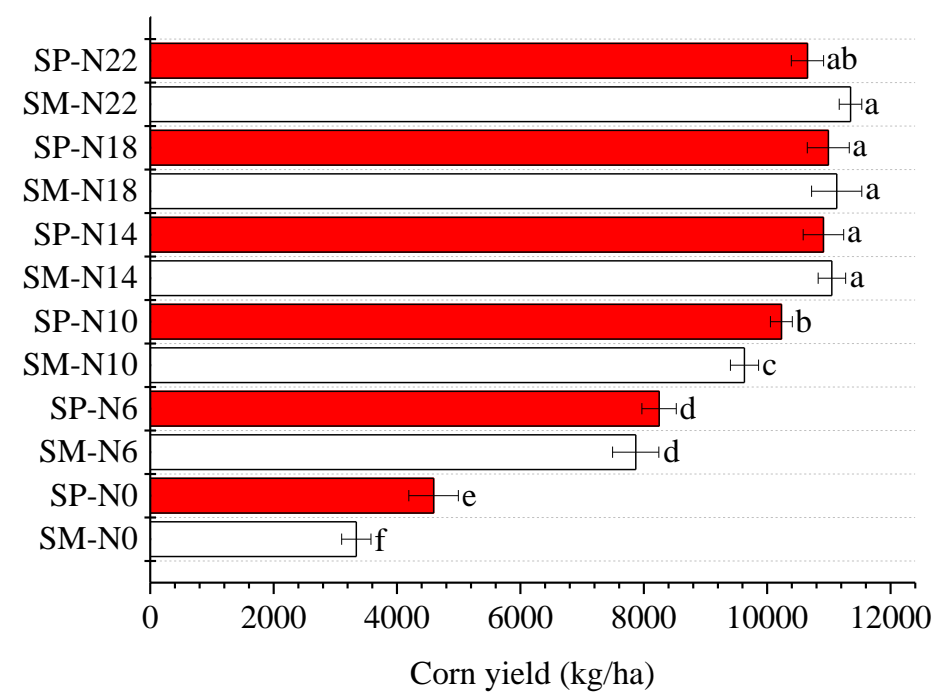

Figure 1. Effects of different straw returning method and nitrogen fertilizer application rates on corn yield. SP: straw ploughing; SM: straw mulching; NO, N6, N10, N14, N18, N22 represents the nitrogen fertilizer application rates level of 0,90,150,210,270,330 kg/ha, respectively

Under the same fertilizer application rate $(210 \mathrm{~kg} / \mathrm{ha})$, corn yield at no residue addition treatment was significantly lower than that at the residual return amount of $9000 \mathrm{~kg} / \mathrm{ha}$ (Fig. 2). There were no significant differences for crop yield among different residual return amount of 0,4500 and $13500 \mathrm{~kg} /$ ha treatment (Fig. 2). No residue addition, straw mulching and straw ploughing had no significant $(\mathrm{P}>0.05)$ effect on crop yield under the same fertilizer application rate (Fig. 2).

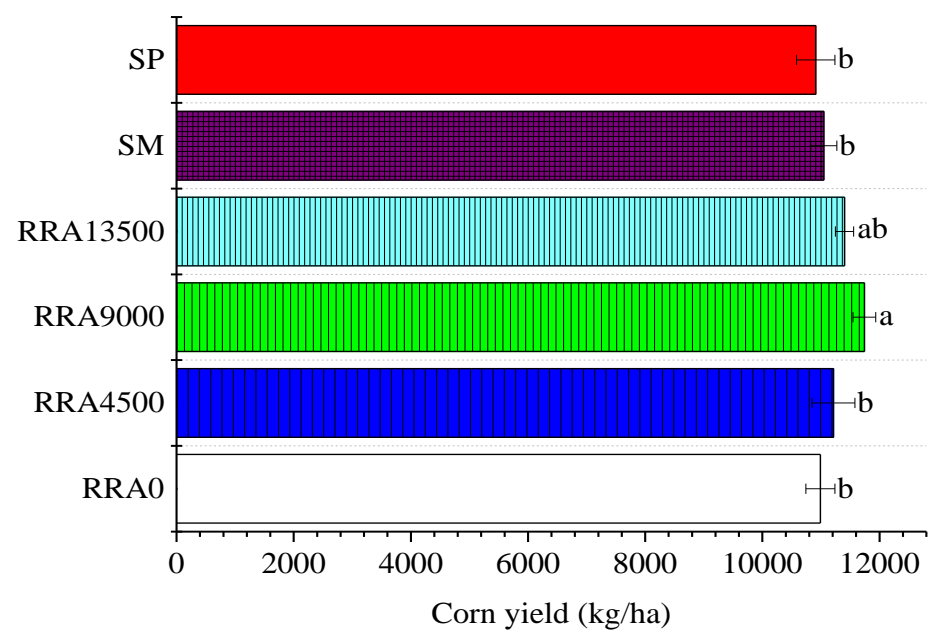

Figure 2. Effects of different residual return amount and straw returning method on corn yield under the same fertilizer application rate $(210 \mathrm{~kg} / \mathrm{ha})$. SP: straw ploughing; SM: straw mulching; RRA0, RRA4500, RRA9000, RRA13500 represents the residual return amount of 0 , 4500, 9000, $13500 \mathrm{~kg} / \mathrm{ha}$, respectively 
Change in crop yield by straw returning method and nitrogen fertilizer application rates was significantly affected by the nitrogen fertilizer application rates of 0-90 and $0-150 \mathrm{~kg} / \mathrm{ha}$, but it was not affected by $0-210,0-270$ and $0-330 \mathrm{~kg} / \mathrm{ha}$ (Table 2).

Table 2. Analysis of Variance for straw returning method and nitrogen fertilizer application effects on crop yield

\begin{tabular}{|c|c|c|c|c|c|c|}
\hline $\begin{array}{c}\text { Different range of nitrogen } \\
\text { fertilizer application rates } \\
\text { (kg/ha) }\end{array}$ & & Sum of Squares & df & Mean Square & $\mathbf{F}$ & Sig. \\
\hline \multirow[t]{3}{*}{$0-90$} & Between Groups (Replicate) & 1141448.167 & 1 & 1141448.167 & 53.991 & 0.002 \\
\hline & Within Groups (Error) & 84565.333 & 4 & 21141.333 & & \\
\hline & Total & 1226013.5 & 5 & & & \\
\hline \multirow[t]{3}{*}{$0-150$} & Between Groups (Replicate) & 639613.5 & 1 & 639613.5 & 6.717 & 0.044 \\
\hline & Within Groups (Error) & 380920 & 4 & 95230 & & \\
\hline & Total & 1020533.5 & 5 & & & \\
\hline \multirow[t]{3}{*}{$0-210$} & Between Groups (Replicate) & 2891204.167 & 1 & 2891204.167 & 8.442 & 0.061 \\
\hline & Within Groups (Error) & 1369880.667 & 4 & 342470.167 & & \\
\hline & Total & 4261084.834 & 5 & & & \\
\hline \multirow[t]{3}{*}{$0-270$} & Between Groups (Replicate) & 2888428.167 & 1 & 2888428.167 & 15.48 & 0.067 \\
\hline & Within Groups (Error) & 746386.667 & 4 & 186596.667 & & \\
\hline & Total & 3634814.834 & 5 & & & \\
\hline \multirow[t]{3}{*}{$0-330$} & Between Groups (Replicate) & 5709601.5 & 1 & 5709601.5 & 18.708 & 0.072 \\
\hline & Within Groups (Error) & 1220798 & 4 & 305199.5 & & \\
\hline & Total & 6930399.5 & 5 & & & \\
\hline
\end{tabular}

\section{Effects of straw returning and nitrogen fertilizer application on nitrogen utilization}

Under the same nitrogen fertilizer application rate $(210 \mathrm{~kg} / \mathrm{ha})$, straw returning method affected corn nitrogen uptake significantly (Table 3). Both straw mulching and straw ploughing had significantly $(\mathrm{P}<0.05)$ greater corn nitrogen uptake than no residue addition treatment (Table 3). A similar trend was also found for the soil total nitrogen (Table 3). Though straw ploughing resulted in similar corn nitrogen uptake and soil total nitrogen values with straw mulching, the former was $1.33 \%$ and $4.43 \%$ higher than the latter, respectively (Table 3). Nitrogen harvest index in straw ploughing was significantly higher than in no residue addition and straw mulching treatments $(\mathrm{P}<0.05)$ (Table 3). Nitrogen partial factor productivity among the residual return methods was not significantly different $(\mathrm{P}>0.05)$ (Table 3$)$.

Table 3. Mean values (standard errors in parentheses) of corn nitrogen uptake, nitrogen partial factor productivity, nitrogen harvest index and soil total nitrogen for different treatments

\begin{tabular}{c|c|c|c|c}
\hline Treatment & $\begin{array}{c}\text { Corn nitrogen } \\
\text { uptake (kg/ha) }\end{array}$ & $\begin{array}{c}\text { Nitrogen partial factor } \\
\text { productivity (kg/kg) }\end{array}$ & $\begin{array}{c}\text { Nitrogen harvest } \\
\text { index (\%) }\end{array}$ & $\begin{array}{c}\text { Soil total } \\
\text { nitrogen (g/kg) }\end{array}$ \\
\hline No residue addition & $206.57(3.30) \mathrm{b}$ & $52.34(0.68) \mathrm{a}$ & $66.86(0.54) \mathrm{b}$ & $1.49(0.01) \mathrm{b}$ \\
Straw mulching & $218.43(2.42) \mathrm{a}$ & $52.61(0.61) \mathrm{a}$ & $65.44(0.41) \mathrm{b}$ & $1.58(0.02) \mathrm{a}$ \\
Straw ploughing & $221.33(1.27) \mathrm{a}$ & $51.97(0.91) \mathrm{a}$ & $69.72(0.52) \mathrm{a}$ & $1.65(0.03) \mathrm{a}$ \\
\hline
\end{tabular}

Different lowercase letters in a column means significant difference between treatments at $\mathrm{P}<0.05$ 


\section{Discussion}

\section{Effects of straw returning and nitrogen fertilizer application on crop yield}

According to the multifactor interaction analysis, neither the straw returning method nor the residual return amount affected crop yield. However, nitrogen fertilizer application rates have a significant impact on crop yield. This implies there exists a longterm cumulative process about the effects of combined straw returning and nitrogen application on crop yield and this effect does not appear immediately. The reason for this situation was that soil nitrogen supply capacity would be reduced in the early stage of straw returning and this was not conducive to early crop growth (Nasielski and Deen, 2019), thus in that case nitrogen fertilizer should be applied in conjunction to regulate soil nitrogen content for crop growth (Harindintwali et al., 2021). What this paper showed was the fifth year result of the experiment, another reason may be due to the lower decay rate of residue. For residual return amount, lower amount did not manifest beneficial effects on crop yield (Li et al., 2018) whereas higher amount changed carbon and nitrogen transformation in soil ecosystem and further nitrogen supply capacity (Qin et al., 2021). So when residual return amount reached a certain critical value, it would affect crop growth. Similar result was obtained by Yin et al. (2018) who found corn yield was not affected by straw returning under different nitrogen fertilizer application rates. Significant effect was observed in the influence of the $S R M \times N F A R$ interaction on crop yield. It was mainly attributed to the important role of nitrogen fertilizer application. Straw ploughing resulted in higher crop yield under N0, N6, N10 relative to straw mulching. The possible explanation was nitrogen fertilizer application took more important effect on crop yield under the combination of straw returning and nitrogen fertilizer application. On the other hand, it can be seen that the combination of nitrogen fertilizer application and straw ploughing is more beneficial to crop growth than straw mulching. No significant effect on crop yield were observed between straw ploughing and straw mulching under the nitrogen fertilizer application rates $>150 \mathrm{~kg} / \mathrm{ha}(\mathrm{N} 14, \mathrm{~N} 18, \mathrm{~N} 22)$. This means there exists a threshold value of nitrogen fertilizer application rates to affect crop growth. It was consistent with those reported by Sadeghi et al. (2018) who found when the nitrogen application rate increased to a certain extent, the increment in crop yield would be less pronounced, and it may even show a downward trend. No residue addition treatment resulted in significantly lower corn yield than that at the residual return amount of $9000 \mathrm{~kg} / \mathrm{ha}$ under the same fertilizer application rate $(210 \mathrm{~kg} / \mathrm{ha})$. It indicated that no residual returning certainly do no good to crop growth. Furthermore, different residual return amount of 0,4500 and $13500 \mathrm{~kg} / \mathrm{ha}$ treatment had no significant $(\mathrm{P}>0.05)$ effect on crop yield. These results suggest that $9000 \mathrm{~kg} / \mathrm{ha}$ should be the optimum residual return amount considering $210 \mathrm{~kg} / \mathrm{ha}$ is the amount of nitrogen fertilizer applied by local farmers (Yu et al., 2021). It also confirms the critical value of residual return amount as discussed before. There were no significant differences for crop yield among no residue addition, straw mulching and straw ploughing under the same fertilizer application rate. This result means straw returning method is not decisive to crop yield under the same fertilizer application rate. In other words, either straw ploughing or straw mulching is a good way to avoid straw burning-caused environmental problems compared with no residue addition. The result that change in crop yield by residual return method and nitrogen fertilizer application rates was significantly affected by the nitrogen fertilizer application rates of $0-90$ and $0-150 \mathrm{~kg} / \mathrm{ha}$ rather than $0-210,0-270$ and $0-330 \mathrm{~kg} / \mathrm{ha}$ verifies the above threshold value of nitrogen fertilizer application rates on crop growth. This illustrated that 
$150 \mathrm{~kg} / \mathrm{ha}$ was the optimum amount of nitrogen fertilizer application rates on crop yield in this study.

\section{Effects of straw returning and nitrogen fertilizer application on nitrogen utilization}

In order to facilitate comparison, this study compared the effects of straw returning and nitrogen fertilizer application on nitrogen utilization under the same fertilizer application rate $(210 \mathrm{~kg} / \mathrm{ha})$. Both straw mulching and straw ploughing led to significantly greater corn nitrogen uptake compared to no residue addition treatment $(\mathrm{P}<0.05)$. This was mainly related to the fact that nitrogen of returned straw was released during the decomposition process and increasing the soil nitrogen supply (Nafi et al., 2019). It was agreed upon by previous research (Fang et al., 2018) whereas contrasted with the study of Chen et al. (2014). The underlying reason for this was different crop cultivation systems, different field management methods and different temperature and climate would all affect the results of straw returning and nitrogen fertilizer application on corn nitrogen uptake. Interestingly, the corn nitrogen uptake in either straw mulching or straw ploughing was greater than the nitrogen fertilizer application rate. Since crop absorption is the main way of soil nitrogen expenditure, this also explains the promotion effect of straw returning on corn nitrogen uptake. Straw returning method resulted in significantly different values of soil total nitrogen $(\mathrm{P}<0.05)$. In contrast to no residue addition, both straw mulching and straw ploughing had a significantly greater soil total nitrogen. This was in accordance with the results obtained by Xue et al. (2015) who found straw ploughing and straw mulching increased soil total nitrogen significantly on the topsoil. Dong et al. (2018) further pointed out that straw ploughing increased soil total nitrogen than no residue addition treatment. It was owing to the fact that residual itself as an organic fertilizer could improve total nitrogen fixation when mixed with topsoil. This result indicated that either residue added on the soil surface or residue incorporated into soil was more favorable for nitrogen retention than no residue addition on soil under the same fertilizer application rate. The reason why straw ploughing resulted in similar corn nitrogen uptake and soil total nitrogen values with straw mulching whereas the former was a little higher than the latter was different position of straw in soil and different contact degree with soil affecting the decomposition rate and soil nitrogen supply. Nitrogen harvest index reflects the sensitivity of grain to nitrogen and indicates the efficiency of nitrogen transfer to grain (Banger et al., 2019). In current study, nitrogen harvest index in straw ploughing was significantly higher than no residue addition and straw mulching treatment. It indicated that straw ploughing could better promote the transfer of nitrogen absorbed by the plant to the grain. There are many parameters to characterize the use efficiency of nitrogen fertilizer, but nitrogen partial factor productivity is commonly used in the international agricultural community (Cordero et al., 2019). Because it does not need blank area yield and nutrient absorption measurement, and it is simple and clear for farmers to master (Obade, 2019). Generally speaking, nitrogen partial factor productivity decreases with the increment of nitrogen fertilizer applied rates and straw returning can increase the nitrogen partial factor productivity (Hamoud et al., 2019). It was worth noting that straw returning methods did not significantly affect nitrogen partial factor productivity in the present study. This means that nitrogen partial factor productivity is related with the threshold value of nitrogen fertilizer application rates. When the critical value is reached, nitrogen partial factor productivity does not change much. Combined with the previous analysis, here it confirms $150 \mathrm{~kg} / \mathrm{ha}$ was the optimum amount of nitrogen fertilizer application rates on 
crop yield again in this study. Synthesize the above discussion, straw ploughing is more beneficial to nitrogen uptake, utilization, harvest and retention than straw mulching and no residue addition treatment when combined with nitrogen fertilizer application. Therefore, it is better to use the combination of straw ploughing and $150 \mathrm{~kg} / \mathrm{ha}$ nitrogen fertilizer application rates when taking into account both reduced fertilization and improved soil fertility in the chernozem of Northeast China.

\section{Conclusion}

In the present study, we investigated the effects of strawing return and nitrogen fertilizer application on crop yield and nitrogen utilization. Our results revealed that nitrogen fertilizer application rather than straw returning method was dominate factor affecting crop yield when using the combination of straw returning and nitrogen fertilizer application. Straw ploughing had a significantly higher crop yield under the nitrogen fertilizer application rates of $0,90,150 \mathrm{~kg} / \mathrm{ha}$ contrasted with straw mulching. No significant differences were found for nitrogen fertilizer application rates $>150 \mathrm{~kg} / \mathrm{ha}$ on crop yield between straw ploughing and straw mulching. Under the same fertilizer application rate, the optimum residual return amount was $9000 \mathrm{~kg} / \mathrm{ha}$ and straw returning method was not decisive to crop yield. Among different straw returning method, straw ploughing is more favorable to nitrogen uptake, utilization, harvest and retention than straw mulching and no residue addition treatment when combined with nitrogen fertilizer application. Consequently, straw ploughing and $150 \mathrm{~kg} / \mathrm{ha}$ nitrogen fertilizer application rates would be a better option when considering crop yield stabilization and nitrogen utilization improvement simultaneously in the chernozem of Northeast China. Future studies are needed on how to apply and extend this combination management practice to the agricultural field.

Acknowledgements. This research was funded by the Key Research and Development Project of Jilin Province (20200402103NC), Major Science and Technology Project of Jilin Province (20200503004SF), Innovation Leadership and Team Program in Sciences and Technologies for Young and Middle-aged Scientists of Jilin Province (20200301022RQ).

\section{REFERENCES}

[1] Ahmed, M., Rauf, M., Mukhtar, Z., Saeed, N. A. (2017): Excessive use of nitrogenous fertilizers: an unawareness causing serious threats to environment and human health. Environmental Science and Pollution Research 24(35): 26983-26987.

[2] Asibi, A. E., Chai, Q., Coulter, J. A. (2019): Mechanisms of nitrogen use in maize. Agronomy-Basel 9(12): 775.

[3] Banger, K., Nafziger, E. D., Wang, J. M., Pittelkow, C. M. (2019): Modeling inorganic soil nitrogen status in maize agroecosystems. - Soil Science Society of America Journal 83(5): 1564-1574.

[4] Chen, C. C., Han, G. Q., He, H. Q., Westcott, M. (2011): Yield, protein, and remobilization of water soluble carbohydrate and nitrogen of three spring wheat cultivars as influenced by nitrogen input. - Agronomy Journal 103(3): 786-795.

[5] Chen, B. Q., Liu, E. K., Tian, Q. Z., Yan, C. R., Zhang, Y. Q. (2014): Soil nitrogen dynamics and crop residues. A review. - Agronomy for Sustainable Development 34(2): 429-442. 
[6] Cordero, E., Longchamps, L., Khosla, R., Sacco, D. (2019): Spatial management strategies for nitrogen in maize production based on soil and crop data. - Science of the Total Environment 697: 133854.

[7] Dimkpa, C. O., Fugice, J., Singh, U., Lewis, T. D. (2020): Development of fertilizers for enhanced nitrogen use efficiency - Trends and perspectives. - Science of The Total Environment 731: 139113.

[8] Dong, Q. G., Yang, Y. C., Yu, K., Feng, H. (2018): Effects of straw mulching and plastic film mulching on improving soil organic carbon and nitrogen fractions, crop yield and water use efficiency in the Loess Plateau, China. - Agricultural Water Management 201: 133-143.

[9] Fang, Y. Y., Nazaries, L., Singh, B. K., Singh, B. P. (2018): Microbial mechanisms of carbon priming effects revealed during the interaction of crop residue and nutrient inputs in contrasting soils. - Global Change Biology 24(7): 2775-2790.

[10] FAO. (1998): World reference base for soil resources. - Food and Agriculture Organization of the United Nations, Rome.

[11] Farooq, N., Iqbal, M., Farooq, M., Zahir, Z. A. (2019): Interactive effects of synthetic fertilizer and organic residue inputs on soil fertility and wheat crop under various moisture regimes. - International Journal of Agriculture and Biology 21(1): 244-250.

[12] Guan, X. K., Wei, L., Turner, N. C., Ma, S. C., Yang, M. D., Wang, T. C. (2020): Improved straw management practices promote in situ straw decomposition and nutrient release, and increase crop production. - Journal of Cleaner Production 250: 119514.

[13] Hamoud, Y. A., Shaghaleh, H., Sheteiwy, M., Guo, X. P., Elshaikh, N. A., Khan, N. U., Oumarou, A., Rahim, S. F. (2019): Impact of alternative wetting and soil drying and soil clay content on the morphological and physiological traits of rice roots and their relationships to yield and nutrient use-efficiency. - Agricultural Water Management 223: 105706.

[14] Harindintwali, J. D., Zhou, J. L., Muhoza, B., Wang, F., Herzberger, A., Yu, X. B. (2021): Integrated eco-strategies towards sustainable carbon and nitrogen cycling in agriculture. Journal of Environmental management 293: 112856.

[15] Huang, D. D., Chen, X. W., Cao, G. J., Liang, A. Z., Jia, S. X., Liu, S. X. (2018): Effects of long-term conservation tillage on soil nitrogen content and organic nitrogen components in a Chinese Mollisol. - Applied Ecology and Environmental Research 16(5): 5517-5528.

[16] Janke, C. K., Moody, P., Bell, M. J. (2020): Three-dimensional dynamics of nitrogen from banded enhanced efficiency fertilizers. - Nutrient Cycling in Agroecosystems 118(3): 227247.

[17] Li, H., Dai, M. W., Dai, S. L., Dong, X. J. (2018): Current status and environment impact of direct straw return in China's cropland - A review. - Ecotoxicology and Environmental Safety 159: 293-300.

[18] Li, G. H., Cheng, G. G., Lu, W. P., Lu, D. L. (2021): Differences of yield and nitrogen use efficiency under different applications of slow release fertilizer in spring maize. - Journal of Integrative Agriculture 20(2): 554-564.

[19] Ma, Q., Jiang, C. M., Li, S. L., Yu, W. T. (2021): Maize yield and nitrogen-use characteristics were promoted as consistently improved soil fertility: 6-year straw incorporation in Northeast China. - Plant Soil and Environment 67(7): 383-389.

[20] Mabagala, F. S., Geng, Y. H., Cao, G. J., Wang, L. C., Wang, M., Zhang, M. L. (2020): Effect of silicon on crop yield, and nitrogen use efficiency applied under straw return treatments. - Applied Ecology and Environmental Research 18(4): 5577-5590.

[21] Nafi, E., Webber, H., Danso, I., Naab, J. B., Frei, M., Gaiser, T. (2019): Soil tillage, residue management and site interactions affecting nitrogen use efficiency in maize and cotton in the Sudan Savanna of Africa. - Field Crops Research 244: 107629.

[22] Nasielski, J., Deen, B. (2019): Nitrogen applications made close to silking: Implications for yield formation in maize. - Field Crops Research 243: 107621. 
[23] Obade, V. D. (2019): Integrating management information with soil quality dynamics to monitor agricultural productivity. - Science of the Total Environment 651: 2036-2043.

[24] Osterholz, W. R., Liebman, M., Castellano, M. J. (2018): Can soil nitrogen dynamics explain the yield benefit of crop diversification? - Field Crops Research 219: 33-42.

[25] Qin, X. L., Huang, T. T., Lu, C., Dang, P. F., Zhang, M. M., Guan, X. K., Wen, P. F., Wang, T. C., Chen, Y. L., Siddique, K. H. M. (2021): Benefits and limitations of straw mulching and incorporation on maize yield, water use efficiency, and nitrogen use efficiency. - Agricultural Water Management 256: 107128.

[26] Rahman, M. H., Haque, K. M. S., Khan, M. Z. H. (2021): A review on application of controlled released fertilizers influencing the sustainable agricultural production: A Cleaner production process. - Environmental Technology \& Innovation 23: 101697.

[27] Ruffatti, M. D., Roth, R. T., Lacey, C. G., Armstrong, S. D. (2019): Impacts of nitrogen application timing and cover crop inclusion on subsurface drainage water quality. Agricultural Water Management 211: 81-88.

[28] Sadeghi, S. M., Noorhosseini, S. A., Damalas, C. A. (2018): Environmental sustainability of corn (Zea mays L.) production on the basis of nitrogen fertilizer application: The case of Lahijan, Iran. - Renewable \& Sustainable Energy Reviews 95: 48-55.

[29] Sawyer, J. E., Woli, K. P., Barker, D. W., Pantoja, J. L. (2017): Stover Removal Impact on Corn Plant Biomass, Nitrogen, and Use Efficiency. - Agronomy Journal 109(3): 802-810.

[30] Tenelli, S., Otto, R., Bordonal, R. O., Carvalho, J. L. N. (2021): How do nitrogen fertilization and cover crop influence soil C-N stocks and subsequent yields of sugarcane? - Soil \& Tillage Research 211: 104999.

[31] Wang, M., Pendall, E., Fang, C. M., Li, B., Nie, M. (2018): A global perspective on agroecosystem nitrogen cycles after returning crop residue. - Agriculture Ecosystems \& Environment 266: 49-54.

[32] Weih, M., Hamner, K., Pourazari, F. (2018): Analyzing plant nutrient uptake and utilization efficiencies: comparison between crops and approaches. - Plant and Soil 430(1-2): 7-21.

[33] Xue, J. F., Pu, C., Liu, S. L., Chen, Z. D., Chen, F., Xiao, X. P., Lal, R., Zhang, H. L. (2015): Effects of tillage systems on soil organic carbon and total nitrogen in a double paddy cropping system in Southern China. - Soil \& Tillage Research 153: 161-168.

[34] Yin, H. J., Zhao, W. Q., Li, T., Cheng, X. Y., Liu, Q. (2018): Balancing straw returning and chemical fertilizers in China: Role of straw nutrient resources. - Renewable \& Sustainable Energy Reviews 81: 2695-2702.

[35] Yu, Y., Qian, C. R., Gu, W. R., Li, C. F. (2021): Responses of root characteristic parameters and plant dry matter accumulation, distribution and transportation to nitrogen levels for spring maize in Northeast China. - Agriculture-Basel 11(4): 308.

[36] Zhao, J. L., Lu, Y., Tian, H. L., Jia, H. L., Guo, M. Z. (2019): Effects of straw returning and residue cleaner on the soil moisture content, soil temperature, and maize emergence rate in China's three major maize producing areas. - Sustainability 11(20): 5796. 